Bi et al., Afr J Tradit Complement Altern Med., (2017) 14 (4): 221-238

https://doi.org/10.21010/ajtcam.v14i4.25

\title{
ANTI-ULCEROGENIC EFFICACY AND MECHANISMS OF EDIBLE AND NATURAL INGREDIENTS IN NSAID-INDUCED ANIMAL MODELS
}

\author{
Weiping Bi ${ }^{1}$, Lizhi Hu², Mao-Qiang Man $^{3}$ \\ ${ }^{1}$ Weihai Central Hospital, Wendeng City, Shandong, 264400, P.R. China; ${ }^{2}$ Department of Pathogen Biology and \\ Immunology, Basic Medical College, Tianjin Medical University, Tianjin 300070, P. R. China; ${ }^{3}$ Dermatology \\ Service, Veterans Affairs Medical Center San Francisco, and Department of Dermatology, University of \\ California San Francisco, CA, USA.
}

Corresponding author E- Mail: mqman@hotmail.com

\begin{abstract}
Background: Nonsteroidal anti-inflammatory drugs (NSAIDs) are a class of the most commonly used medicines and proven to be effective for certain disorders. Some people use NSAIDs on daily basis for preventive purpose. But a variety of severe side effects can be induced by NSAIDs. Studies have shown that edible natural ingredients exhibit preventive benefit of gastric ulcer. This paper reviews the efficacy and safety of edible natural ingredients in preventing the development of gastric ulcer induced by NSAIDs in animal models.

Methods: A systematic literature search was conducted on PubMed, using the terms "herbal medicines" and "gastric ulcer", "herbal medicines" and "peptic ulcer", "food" and "peptic ulcer", "food" and "gastric ulcer", "natural ingredient" and "peptic ulcer", "natural ingredient" and "gastric ulcer", "alternative medicine" and "peptic ulcer", "alternative medicine" and "gastric ulcer", "complementary medicine" and "peptic ulcer", "complementary medicine" and "gastric ulcer" in papers published in English between January 1, 1960 and January 31, 2016, resulting in a total of 6146 articles containing these terms. After exclusion of studies not related prevention, not in NSAID model or using non-edible natural ingredients, 54 articles were included in this review.

Results: Numerous studies have demonstrated that edible natural ingredients exhibit antiulcerogenic benefit in NSAIDinduced animal models. The mechanisms by which edible, ingredient-induced anti-ulcerogenic effects include stimulation of mucous cell proliferation, antioxidation, inhibition of gastric acid secretion, as well as inhibition of $\mathrm{H}(+), \mathrm{K}(+)-\mathrm{ATPase}$ activities. Utilization of edible, natural ingredients could be a safe, valuable alternative to prevent the development of NSAID-induced gastric ulcer, particularly for the subjects who are long-term users of NSAIDs.
\end{abstract}

Key Words: Food, Gastric ulcer, Prevention, Animal models, Nonsteroidal anti-inflammatory drugs.

Abbreviation: SOD: superoxide dismutase; GSH: glutathione; MDA: malondialdehyde; NSAIDs: nonsteroidal antiinflammatory drugs

\section{Introduction}

NSAIDs have been widely used for centuries for the treatment and prevention of various disorders (Wright, 1995). The therapeutic benefits of NSAIDs include relief of fever, pain, inflammation and depression (Cilliers, et al., 2015; Cremonesi and Cavalieri., 2015; Enthoven, et al., 2016; Köhler, et al., 2014). Long term use of aspirin, a NSAID, reduces the risk of and mortality of cardiovascular diseases, ischemic stroke, colorectal cancer and myocardial infarction (Dehmer, et al., 2016). But, NSAIDs can also increase the risk of developing gastric ulcer, hemorrhagic stroke and GI bleeding (Dehmer, et al., 2016; García Rodríguez et al., 2001, 2004; Kang et al., 2011, 2012; Voutilainen et al.,2001; Yamagata and Hiraishi., 2007). Up to $13 \%$ of patients with gastric ulcer are NSAIDs users (Konturek, et al., 2003) while gastric ulcer is a risk factor of gastric cancer (Hansson et al., 1996; Molloy and Sonnenberg., 1997), and negatively impact the quality of patients' life, the work productivity and medical burden (Barkun et al., 2010; Sonnenberg and Everhart., 1997). Thus, these harmful effects of NSAIDs refrain it from being widely used in preventing and treating certain diseases, which require long-term use of NSAIDs. Although esomeprazole and proton pump inhibitors can effectively prevent NSAIDs-induced side effects (Hsiao, et al., 2009; Scheiman, et al., 2013a,b; Sylvester, et al., 2013), these drugs can induce severe adverse events, including microscopic colitis (Masclee, et al., 2015; Verhaegh, et al., 2016), galactorrhea (Pipaliya, et al., 2016), and reduced bone mineral density (Ozdil, et al., 2013). In contrast, studies have demonstrated that edible, natural ingredients can effectively prevent the formation of gastric ulcer with fewer side effects in various animal models including NSAID- 
Bi et al., Afr J Tradit Complement Altern Med., (2017) 14 (4): 221-238

https://doi.org/10.21010/ajtcam.v14i4.25

induced gastric ulcer, suggesting the potential utilization of these ingredients for preventing gastric ulcer for subjects who take NSAIDs for long-term. We summarize here the antiulcerogenic benefits of certain edible, natural ingredients and the mechanisms of their action in NSAID-induced model of gastric ulcer. Literature search terms and methods are detailed in Table 1

Table 1: Search Terms and Results

\begin{tabular}{lcll}
\hline \multicolumn{1}{c}{ Search Term } & Results & \multicolumn{1}{c}{ Exclusion } & Number of Papers Reviewed \\
\hline $\begin{array}{l}\text { Alternative medicine, peptic } \\
\text { ulcer }\end{array}$ & 690 & \\
$\begin{array}{l}\text { Alternative medicine, gastric } \\
\text { ulcer }\end{array}$ & 652 & Full paper is not available \\
Chinese Medicine, gastric ulcer & 208 & online; \\
Chinese Medicine, peptic ulcer & 257 & Not related prevention; \\
Complementary medicine, peptic & 568 & Not in NSAID-induced \\
ulcer & & gastric ulcer model; \\
Complementary medicine, & 557 & Using non-edible natural \\
gastric ulcer & 1598 & ingredients; \\
Food, peptic ulcer & 1444 & Animal procedure was not \\
Food, gastric ulcer & 88 & detailed enough to \\
Herbal medicine, gastric ulcer & 83 & determine the dosage and \\
Herbal medicine, peptic ulcer & 0 & pretreatment time. \\
Natural ingredient, peptic ulcer & 1 & \\
Natural ingredient, gastric ulcer & 6146 & \\
Total & & \\
\hline
\end{tabular}


Bi et al., Afr J Tradit Complement Altern Med., (2017) 14 (4): 221-238

https://doi.org/10.21010/ajtcam.v14i4.25

Table 2: Edible Natural Ingredients That Prevent the Development of NSAID-Induced Gastric Ulcer

\begin{tabular}{|c|c|c|c|c|c|c|c|}
\hline \multirow[b]{2}{*}{ Natural Ingredients } & \multirow[b]{2}{*}{ Species } & \multirow[b]{2}{*}{$\begin{array}{l}\text { Pretreatment } \\
\text { Time }\end{array}$} & \multicolumn{2}{|c|}{ Herbal Ingredient } & \multicolumn{2}{|c|}{ Positive Control } & \multirow[b]{2}{*}{ References } \\
\hline & & & $\begin{array}{c}\text { Dose } \\
\text { (mg/kg body } \\
\text { weight) }\end{array}$ & $\begin{array}{l}\text { Inhibition } \\
(\%)\end{array}$ & $\begin{array}{c}\text { Dose } \\
\text { (mg/kg body } \\
\text { weight) }\end{array}$ & $\begin{array}{l}\text { Inhibi } \\
\text { tion } \\
(\%)\end{array}$ & \\
\hline Leaves of Mouriri pusa & Mouse & $30 \mathrm{~min}$ & $\begin{array}{c}250 \\
500 \\
1000\end{array}$ & $\begin{array}{l}51 \\
60 \\
65\end{array}$ & 30 & 49 & $\begin{array}{l}\text { (Andreo et } \\
\text { al.,2003) }\end{array}$ \\
\hline $\begin{array}{l}\text { Trichosanthes cucumerina } \\
\text { (aerial parts) }\end{array}$ & Rat & $1 \mathrm{Hr}$ after & 750 & 88 & 100 & 90 & $\begin{array}{c}\text { (Arawwawala et } \\
\text { al., 2010) }\end{array}$ \\
\hline $\begin{array}{l}\text { Musa sapientum var. } \\
\text { paradisiaca fruits }\end{array}$ & Rat & $\begin{array}{c}3 \text { days } \\
\text { with NSAID }\end{array}$ & 500 & 68 & $\mathrm{~N} / \mathrm{D}$ & & $\begin{array}{c}\text { (Goel et al., } \\
\text { 1985,1986,2001; } \\
\text { Lewis et al., } \\
\text { 1999) }\end{array}$ \\
\hline Phyllanthus emblica fruits & Rat & 10 days & $\begin{array}{c}60 \\
80 \\
100 \\
120\end{array}$ & $\begin{array}{l}14 \\
36 \\
86 \\
87\end{array}$ & $\mathrm{~N} / \mathrm{D}$ & & $\begin{array}{l}\text { (Bandyopadhyay } \\
\text { et al., 2000) }\end{array}$ \\
\hline $\begin{array}{l}\text { Syngonanthus arthrotrichus } \\
\text { Silveira }\end{array}$ & Rat & $30 \mathrm{~min}$ & $\begin{array}{l}100 \\
250\end{array}$ & $\begin{array}{l}55 \\
32\end{array}$ & 100 & & $\begin{array}{l}\text { (Batista et } \\
\text { al., 2004) }\end{array}$ \\
\hline $\begin{array}{l}\text { Asparagus racemosus } \\
\text { Willd. }\end{array}$ & Rat & $\begin{array}{c}15 \text { days } \\
\text { with NSAID }\end{array}$ & 100 & 82 & 30 & & $\begin{array}{l}\text { (Bhatnagar } \\
\text { and } \\
\text { Sisodia., } \\
\text { 2006) }\end{array}$ \\
\hline $\begin{array}{l}\text { Ocimum basilicum (aerial } \\
\text { parts) } \\
\text { Solanum nigrum (aerial } \\
\text { parts) }\end{array}$ & Rat & 3 days & 4000 & $\begin{array}{l}35^{4}, 37^{5} \\
3^{4}, 23^{5}\end{array}$ & 30 & & $\begin{array}{c}\text { (Akhtar } \\
\text { and Munir., } \\
\text { 1989) }\end{array}$ \\
\hline
\end{tabular}


Bi et al., Afr J Tradit Complement Altern Med., (2017) 14 (4): 221-238

https://doi.org/10.21010/ajtcam.v14i4.25

Brassica oleracea var.

botrytis L. (aerial parts)

Brassica olerace var.

acephala DC (leaves)

Combretum duarteanum

Cambess (leaves)

Mouse

Ginseng

Arctium lappa L. roots

Mouse

$30 \mathrm{~min}$

Fruit extract of Aegle marmelos Corr

Rat

14 days

250

100

Grape seed

Rat

6 days

300

1 day

7 days

Garcinia kola Heckel seed

Rat

$45 \min$

200

Rat

$30 \mathrm{~min}$

100

Petroselinum crispum

1000
$42^{4}, 3^{5}$

$$
15
$$

64

66

100

$81 \quad$ (Lemos et

1.3

30

42

49

0

Inhibition

$(\mathrm{N} / \mathrm{Q})^{1}$

68

60

43

93

97

97

94

59
37

(1)

100

(de Morais

$54 \quad$ Lima et al., 2013)

(Oyagi et

al., 2010)

100

(de

61 Almeida et

al., 2012)

(Singh et al., 2015)

$250 \quad 97 \quad \begin{gathered}\text { (Das and } \\ \text { Roy., 2012) }\end{gathered}$

(Abbas and Sakr.,

$0.05 \quad 2013 ; \mathrm{Kim}$

et al.,

2013)

(Olaleye

39 Farombi.,

50

2006)

10

(Onasanwo

et al.,

2011)

(Al- 
Bi et al., Afr J Tradit Complement Altern Med., (2017) 14 (4): 221-238

https://doi.org/10.21010/ajtcam.v14i4.25

(Mill.) (aerial parts)

\begin{tabular}{|c|c|c|c|c|}
\hline & & & 2000 & 46 \\
\hline & & & 250 & 50 \\
\hline & & & 500 & 62 \\
\hline $\begin{array}{l}\text { Amaranthus tricolor } \mathrm{L} . \\
\text { (leaves) }\end{array}$ & & & 200 & $65^{2}, 54^{3}$ \\
\hline $\begin{array}{l}\text { Baccharis dracunculifolia } \\
\text { (Essential Oil) }\end{array}$ & & & $\begin{array}{c}50 \\
250 \\
500\end{array}$ & $\begin{array}{l}80 \\
77 \\
75\end{array}$ \\
\hline & Rat & $1 \mathrm{hr}$ & 50 & 2 \\
\hline Extract of Brazilian green & & & 250 & 6 \\
\hline propolls & & & 500 & 55 \\
\hline Fish oil & & & $5 \mathrm{ml}$ & 74 \\
\hline FISI on & & & $10 \mathrm{ml}$ & 79 \\
\hline & Rat & $30 \mathrm{~min}$ & $5 \mathrm{ml}$ & 32 \\
\hline Evening primrose oil & & & $10 \mathrm{ml}$ & 89 \\
\hline & & & $1 \mathrm{x}$ & 52 \\
\hline Eriobotrya japonica seed & Rat & 14 days & $3 x$ & 71 \\
\hline & & & $5 \mathrm{x}$ & 31 \\
\hline Glycine max L. grains & Rat & 7days & 250 & 26 \\
\hline Gigctile nilax L. grants & Kat & tuays & 500 & 44 \\
\hline & & & 100 & $64^{4}, 31^{5,7}$ \\
\hline Bauhinia purpurea leaves & Rat & $30 \mathrm{~min}$ & 500 & $\begin{array}{l}55^{4}, 51^{5}, \\
24^{7}\end{array}$ \\
\hline
\end{tabular}

Howiriny

$$
\text { et }
$$$$
\text { al.,2003) }
$$$$
\text { (Al- }
$$

Howiriny et al.,2000) (Devaraj and Krishna., 2011)

(Massignan $42 \quad i$ et al. 2009)

100

(Barros et al., 2008;

50 de Barros et al., 2007)

(al-Harbi et al.,1995) (alShabanah , 1997)

25

(Yokota et 69 al., 2008 and 2011)

(Kumar et al., 2013)

(Hisam et al., 2012;

Zakaria et 
Bi et al., Afr J Tradit Complement Altern Med., (2017) 14 (4): 221-238

https://doi.org/10.21010/ajtcam.v14i4.25

\begin{tabular}{|c|c|c|c|c|c|c|c|}
\hline & & & 1000 & $\begin{array}{c}39^{4}, 47^{5} \\
59^{7}\end{array}$ & & & $\begin{array}{l}\text { al., 2011, } \\
\text { 2012) }\end{array}$ \\
\hline \multirow{3}{*}{$\begin{array}{l}\text { Elettaria cardamomum } \\
\text { Maton. fruits }\end{array}$} & \multirow{3}{*}{ Rat } & \multirow{3}{*}{$30 \mathrm{~min}$} & $12.5^{8}$ & 86 & \multirow{3}{*}{50} & \multirow{3}{*}{69} & \multirow{3}{*}{$\begin{array}{l}\text { (Jamal et } \\
\text { al., 2006) }\end{array}$} \\
\hline & & & $\begin{array}{c}12.5^{9} \\
25-50^{9} \\
450^{10}\end{array}$ & $\begin{array}{c}97 \\
100 \\
53\end{array}$ & & & \\
\hline & & & $500^{5}$ & 77 & & & \\
\hline \multirow{2}{*}{$\begin{array}{l}\text { Opuntia ficus-indica var. } \\
\text { Saboten stem }\end{array}$} & \multirow{2}{*}{ Rat } & \multirow{2}{*}{$30 \mathrm{~min}$} & 200 & 65 & \multirow{2}{*}{50} & \multirow{2}{*}{86} & \multirow{2}{*}{$\begin{array}{l}\text { (Lee et al., } \\
\text { 2002) }\end{array}$} \\
\hline & & & 600 & 58 & & & \\
\hline \multirow{2}{*}{ Luffa acutangula fruits } & \multirow{2}{*}{ Rat } & 21 days & $100-400^{4}$ & $6-19$ & \multirow{2}{*}{2.5} & \multirow{2}{*}{75} & \multirow{2}{*}{$\begin{array}{l}\text { (Pimple et } \\
\text { al., 2012) }\end{array}$} \\
\hline & & $\begin{array}{l}\text { With } \\
\text { NSAID }\end{array}$ & $100-400^{5}$ & $21-60$ & & & \\
\hline \multirow{3}{*}{ Citrus lemon Burm. fruits } & \multirow{3}{*}{ Rat } & \multirow{3}{*}{$30 \mathrm{~min}$} & 33 & $37^{11}$ & \multirow{3}{*}{100} & \multirow{3}{*}{67} & \multirow{3}{*}{$\begin{array}{l}\text { (Rozza et } \\
\text { al., 2011) }\end{array}$} \\
\hline & & & 177 & $50^{12}$ & & & \\
\hline & & & 250 & $98^{13}$ & & & \\
\hline \multirow{3}{*}{ Kaempferia parviflora } & \multirow{3}{*}{ Rat } & \multirow{3}{*}{$60 \mathrm{~min}$} & 30 & 90 & \multirow{3}{*}{100} & \multirow{3}{*}{98} & \multirow{3}{*}{$\begin{array}{c}\text { (Rujjanawa } \\
\text { te et } \\
\text { al.,2005) }\end{array}$} \\
\hline & & & 60 & 97 & & & \\
\hline & & & 120 & 95 & & & \\
\hline Morin & Rat & 30 min i.p & 50 & $\approx 85$ & ND & & $\begin{array}{l}\text { (Singh et } \\
\text { al., 2015b) }\end{array}$ \\
\hline $\begin{array}{l}\text { Seeds of Azadirachta } \\
\text { indica }\end{array}$ & Rat & $45 \mathrm{~min}$ & 20 & 53 & 10 & 58 & $\begin{array}{l}\text { (Singh et } \\
\text { al., 2015a) }\end{array}$ \\
\hline \multirow{2}{*}{$\begin{array}{l}\text { Extract of Punicagranatum } \\
\text { L. Fruits }\end{array}$} & \multirow{2}{*}{ Rat } & \multirow{2}{*}{$60 \mathrm{~min}$} & 250 & 22 & \multirow{2}{*}{50} & \multirow{2}{*}{45} & \multirow{2}{*}{$\begin{array}{l}\text { (Ajaikumar } \\
\text { et al., } \\
\text { 2005) }\end{array}$} \\
\hline & & & 500 & 74 & & & \\
\hline Condonopsis pilosula roots & Rat & $60 \mathrm{~min}$ & $\begin{array}{c}5000 \\
10000\end{array}$ & $\begin{array}{l}40 \\
38\end{array}$ & 67.5 & 68 & $\begin{array}{l}\text { (Wang et } \\
\text { al., 1997) }\end{array}$ \\
\hline Potentilla fulgens Wall. ex & Rat & 7 days & 100 & 27 & 50 & 71 & (Laloo et \\
\hline
\end{tabular}


Bi et al., Afr J Tradit Complement Altern Med., (2017) 14 (4): 221-238

https://doi.org/10.21010/ajtcam.v14i4.25

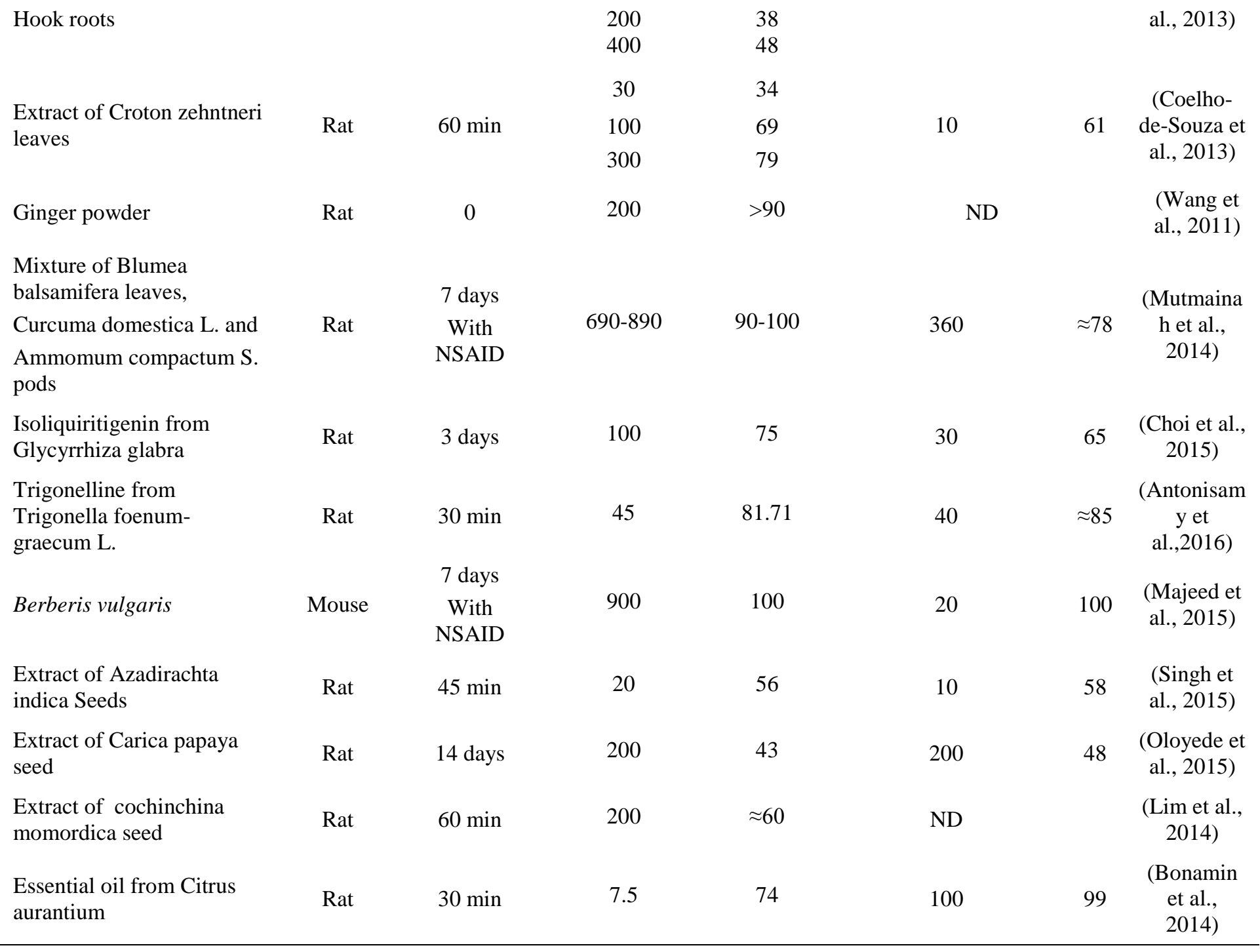

${ }^{1} \mathrm{~N} / \mathrm{Q}:$ not quantitated; ${ }^{2}$ ethanol extract; ${ }^{3}$ ethy acetate extract; ${ }^{4}$ water extract; ${ }^{5}$ methanol extract; ${ }^{6}$ undefined concentration; ${ }^{7}$ chloroform extract; ${ }^{8}$ essential oil; ${ }^{9}$ petroleum ether soluble fraction; ${ }^{10}$ petroleum ether insoluble fraction; ${ }^{11} \beta$-pinene; ${ }^{12}$ limonene; ${ }^{13}$ Citrus lemon. 
Bi et al., Afr J Tradit Complement Altern Med., (2017) 14 (4): 221-238

https://doi.org/10.21010/ajtcam.v14i4.25

\section{Efficacy}

Although no data are available from human study, the antiulcerogenic benefits of edible, natural ingredients have been well demonstrated in animal models, as summarized in Table 2. Both aerial parts and fruits of trichosanthes cucumerina are edible, particularly in Asia. Study demonstrated that orally given $750 \mathrm{mg} / \mathrm{kg}$ body weight of trichosanthes cucumerina extract induced an $88 \%$ reduction in the numbers of haemorrhagic lesions caused by indomethacin in rats. The efficacy was comparable to that induced by conventional drug, cimetidine (100 mg/kg) (Arawwawala et al., 2010). Likewise, asparagus racemosus Willd is a common vegetable. In comparison to indomethacin alone, concurrently oral administrations of asparagus racemosus Willd extract at a daily dose of $100 \mathrm{mg} / \mathrm{kg}$ body weight with indomethacin for 15 days reduced ulcer index by over $80 \%$, which was comparable to that induced by ranitidine at a daily dose of $30 \mathrm{mg} / \mathrm{kg}$ body weight (Bhatnagar and Sisodia., 2006). Moreover, Phyllanthus emblica fruit is commonly edible and available in Asia. Prior to induction of gastric ulcer with indomethacin, orally given Phyllanthus emblica fruit extract for 10 days caused a dosedependent inhibition of ulcer index (Bandyopadhyay et al., 2000). Similarly, orally given pomegranate extract $(500 \mathrm{mg} / \mathrm{kg}$ ) 4 hours prior to aspirin administration induced an over 70\% inhibition of ulcer index (Ajaikumar et al., 1997). Furthermore, edible natural ingredients also prevent the development of gastric ulcer in rats with diabetes, which is a risk factor for gastric ulcer (Masuda et al., 1976; Duggan et al., 1992). Pimple et al. showed that co-administrations of methanolic extract of Luffa acutangula fruits and aspirin could significantly lowered ulcer index in diabetes rats in comparison with aspirin alone (Pimple et al., 2012). Not all edible, natural ingredients display the preventive efficacy in a dose-dependent manner. It has been demonstrated that methanolic extract of Mouriri pusa at a dose of $250 \mathrm{mg} / \mathrm{kg}$ body weight lowered ulcer lesion index by $34 \%$ while $1000 \mathrm{mg} / \mathrm{kg}$ body weight only induced a 7\% inhibition of ulcer lesion index (Andreo et al., 2006). In addition, the inhibitory efficacy of Arctium lappa L.leaves is lower at the dose of $200 \mathrm{mg} / \mathrm{kg}$ body weight than at $50 \mathrm{mg} / \mathrm{kg}$ (de Almeida et al., 2012). Therefore, caution should be taken when determining what dose should be used because the efficacy of certain ingredients not always positively correlates with the dosage.

In addition to vegetables and fruits, certain edible oils also exhibit gastroprotective benefit. For instance, 1 hour prior to induction of ulcer by indomethacin orally given essential oil from Baccharis dracunculifolia at a single dose of $50 \mathrm{mg} / \mathrm{kg}$ body weight induced an 80 inhibition of ulcer index while oral cimetidine at a dose of $100 \mathrm{mg} / \mathrm{kg}$ body weight only caused $42 \%$ inhibition of ulcer index (Massignani et al., 2009). Evening primrose oil, another edible oil, can also dose-dependently prevent the development of gastric ulcer induced by either aspirin or indomethacin (al-Shabanah., 1997). Even the fish oil, one of the most common dietary supplements, displays antiulcerogenic benefit in aspirin- and indomethacin-induced gastric ulcer models of rats (al-Harbi et al., 1995). Moreover, soybean, a commonly consumed food, is a potent antiulcerogenic agent, too. Kumar et al. reported that once daily oral soybean paste 30 min prior to each aspirin administration for 7 days lowered gastric ulcer scores by over $40 \%$ in rats (Kumar et al., 2013). Furthermore, oral administration of extract from a mixture of Blumea balsamifera leaves, Curcuma domestica L. and Ammomum compactum S. pods almost completely prevented the development of aspirin-induced gastric ulcer (Mutmainah et al., 2014). Not only oral administration, but also intraperitoneal injection of food extract shows antiulcerogenic benefit. For example, morin is a flavonoid commonly found in almond, osage orange and fig. 30 min prior to induction of ulcer with indomethacin in rats, intraperitoneal injection of morin at a single dose of $50 \mathrm{mg} / \mathrm{kg}$ body weight reduced ulcer lesion index by over $80 \%$ (Singh et al., 2015).

It is worth noting that the preparation methods can affect the antiulcerogenic efficacy of certain edible ingredients. For instance, dichloromethane extract of Mouriri pusa leaves at a dose of $250 \mathrm{mg} / \mathrm{kg}$ body weight induced a $51 \%$ inhibition of ulcer lesion index while the same dose of methanolic extract caused 34\% inhibition (Andreo et al.,2006). Likewise, aqueous extract of Solanum nigrum at a dose of $4 \mathrm{~g} / \mathrm{kg}$ exhibited no preventive effect in an animal model of aspirin-induced gastric ulcer while the same dose of methanolic extract induced an over 20\% inhibition of ulcer index (Akhtar and Munir., 1989). Similarly, methanolic extract of Luffa acutangula is more effective than its aqueous extract (Rozza et al., 2011). In contrast, aqueous extract of Brassica oleracea, but not methanolic extract, induced a $42 \%$ inhibition of ulcer index (Akhtar and Munir., 1989). However, both aqueous and methanolic extracts of Ocimum basilicum, exhibited a similar efficacy of antiulcerogenesis (Akhtar and Munir., 1989). Therefore, special attention should be paid to the preparation methods when using these ingredients.

\section{Safety}

In addition to soybean and common nutrient supplements such as fish oil and evening primrose oil, other edible, natural ingredients, also are generally safe. For instance, a single of $500 \mathrm{mg} / \mathrm{kg}$ body weight methanolic extract of Mouriri pusa could effectively lower ulcer lesion index (Andreo et al., 2006) while orally given a single dose of $5000 \mathrm{mg} / \mathrm{kg}$ body weight did not cause any signs or symptoms of acute toxicity during a 14-day follow-up period. No lesion or pathological changes occurred in internal organs of the mice (Andreo et al., 2006). Moreover, no adverse event was observed in rats 14 
Bi et al., Afr J Tradit Complement Altern Med., (2017) 14 (4): 221-238

https://doi.org/10.21010/ajtcam.v14i4.25

days after single oral administration of alcoholic extract of Brassica oleracea var. acephala DC leaves, a vegetable, at a dose of $2 \mathrm{~g} / \mathrm{kg}$ body weight (Lemos et al.,2011). The LD50 value for Petroselinum crispum (Mill.) extract is $13 \mathrm{~g} / \mathrm{kg}$ body weight in rats 3 days after a single intraperitoneal injection (Al-Howiriny et al.,2003). All these evidences indicate that edible, natural ingredients are safe for preventing the development of gastric ulcer.

\section{Mechanisms}

While NSAIDs can inhibit inflammation, they also induce the production of proinflammatory cytokines via activation of 5-lipoxygenase pathway (Sinha et al., 2013). NSAIDs can also inhibit prostaglandin E2 synthesis and induce oxidative stress (McAnulty et al., 2007; Sinha et al., 2013), eventually leading to the development of gastric ulcer (Sinha et al., 2013; Tandon et al., 2004). The mechanisms by which edible, natural ingredients display antiulcerogenic benefit include antiinflammation, antioxidaion, stimulation of prostaglandin E2, and inhibition of acid secretion, etc. (Table 3).

\section{a. Antioxidation}

The role of oxidative stress in the pathogenesis of gastric ulcer is well recognized while NSAIDs can induce oxidative stress in various tissues including gastric mucosa (Adachi et al., 2007; Bhattacharyya et al. 2014; Ghosh et al., 2015; Hiraishi et al., 2000; Tandon et al., 2004). Accordingly, employment of antioxidants could benefit gastric ulcer. Studies have shown that the antioxidant property of certain natural ingredients can contribute to their preventive benefits in the development of gastric ulcer in various animal models (Alimi et al., 2010, 2011, 2013;

Table 3: The Mechanisms That Edible Natural Ingredients Prevent Gastric Ulcer

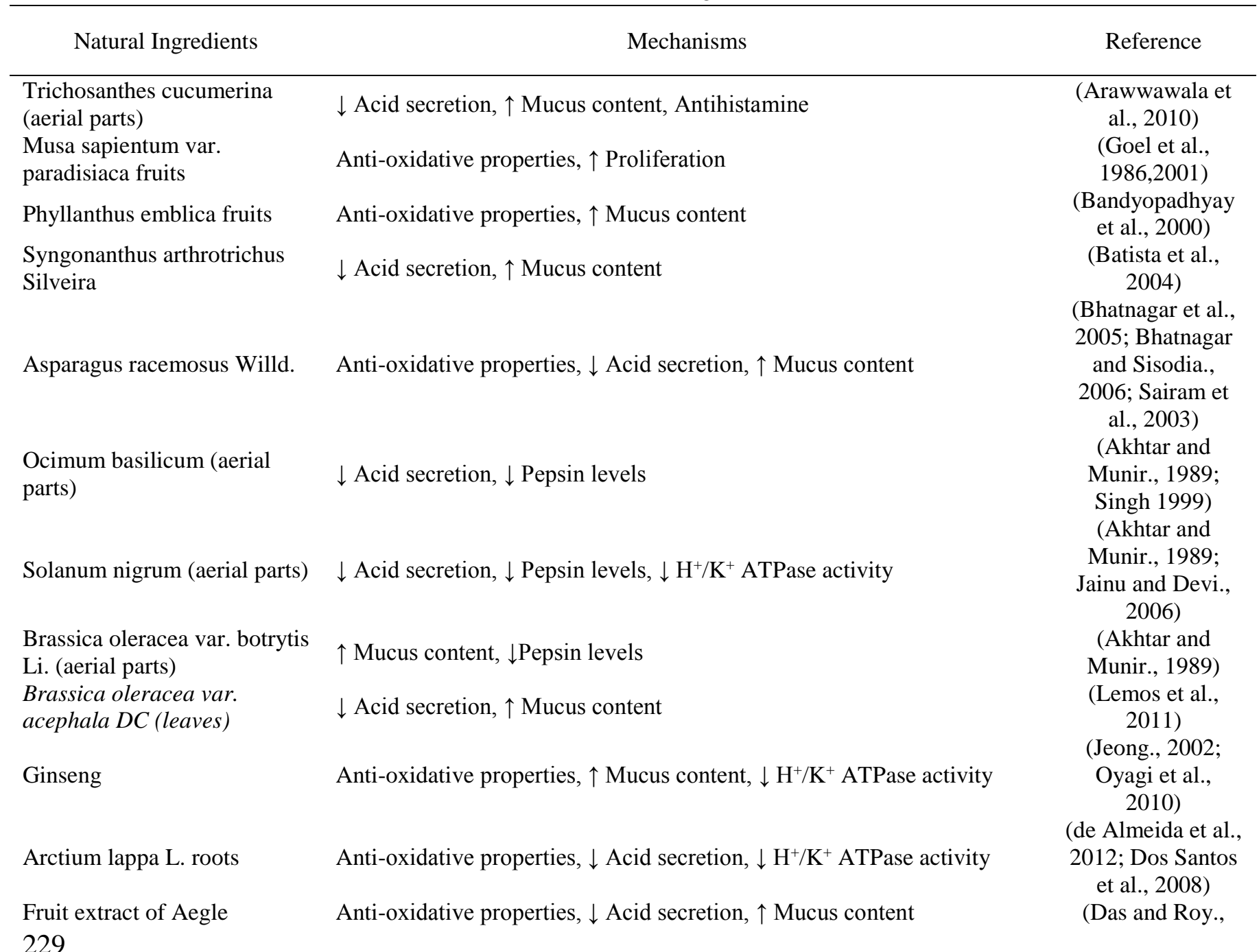


Bi et al., Afr J Tradit Complement Altern Med., (2017) 14 (4): 221-238

https://doi.org/10.21010/ajtcam.v14i4.25

marmelos Corr

Grape seed

$\downarrow$ Inflammation

Garcinia kola Heckel seed

Anti-oxidative properties, $\downarrow$ Acid secretion, $\downarrow \mathrm{H}^{+} / \mathrm{K}^{+}$ATPase activity

Petroselinum crispum (Mill.) (aerial parts)

Baccharis dracunculifolia

(Essential Oil)

Extract of Brazilian green

propolis

Fish oil

Evening primrose oil

Eriobotrya japonica seed

Bauhinia purpurea leaves

Morin

Seeds of Azadirachta indica

Extract of Punicagranatum L. Fruits

Condonopsis pilosula roots

Potentilla fulgens Wall. ex

Hook roots

Extract of Croton zehntneri

leaves

Ginger powder

Mixture of Blumea

balsamifera leaves,

Curcuma domestica L. and

Ammomum compactum S.

pods

Trigonelline from Trigonella foenum-graecum $\mathrm{L}$.

Extract of cochinchina momordica seed

Essential oil from Citrus aurantium
Anti-oxidative properties, $\downarrow$ Acid secretion, $\uparrow$ Mucus content

$\downarrow$ Acid secretion

$\downarrow$ Acid secretion

$\downarrow$ Acid secretion

$\downarrow$ Acid secretion

Anti-oxidative properties, $\uparrow$ Mucus content, $\uparrow$ PGE2

$\downarrow$ Acid secretion, $\uparrow$ Mucus content $\downarrow$ Inflammation

Anti-oxidative properties, $\downarrow$ Inflammation

$\downarrow$ Acid secretion, $\uparrow$ PGE $2, \downarrow \mathrm{H}^{+} / \mathrm{K}^{+}$ATPase activity

Anti-oxidative properties

$\downarrow$ Acid secretion

Anti-oxidative properties, $\downarrow$ Acid secretion, $\uparrow$ Proliferation, $\downarrow \mathrm{H}^{+} / \mathrm{K}^{+}$

ATPase activity, $\downarrow$ Histamine content

$\uparrow$ Mucus content

$\downarrow$ Inflammation ${ }^{1}$

$\downarrow$ Inflammation

$\downarrow$ Inflammation, $\uparrow$ PGE2, Anti-oxidative properties

$\downarrow$ Inflammation, Anti-oxidative properties

$\uparrow$ PGE2, Anti-oxidative properties
2012; Singh et al., 2015)

(Abbas and Sakr., 2013; Kim et al., 2013)

(Olaleye and

Farombi., 2006;

Onasanwo et al., 2011)

(Al-Howiriny et al.,2000; Al-

Howiriny et al.,2003)

(Lemos et al., 2007;Massignani et al., 2009)

(Barros et al., 2008; de Barros et al., 2007)

(al-Harbi et al.,1995)

(al-Shabanah., 1997; Prichard et al., 1988)

(Yokota et al., 2008 and 2011)

(Hisam et al., 2012; Zakaria et al., 2011, 2012)

(Singh et al., 2015b)

(Singh et al., 2015a)

(Ajaikumar et al., 2005)

(Wang et al., 1997)

(Laloo et al., 2013)

(Coelho-de-Souza

et al., 2013)

(Wang et al., 2011)

(Mutmainah et al., 2014)

(Antonisamy et al.,2016)

(Lim et al., 2014)

(Bonamin et al., 2014)

${ }^{1}$ Lowered plasms cytokines; $\downarrow$ : decrease; $\uparrow:$ increase. 
Bi et al., Afr J Tradit Complement Altern Med., (2017) 14 (4): 221-238

https://doi.org/10.21010/ajtcam.v14i4.25

Nartey et al., 2012; Repetto et al., 2002). Bhatnagar et al. reported that oral administration of Asparagus racemosus extract at a daily dose of $100 \mathrm{mg} / \mathrm{kg}$ body weight for 15 days did not only increase the activities of superoxide dismutase (SOD) and catalase (CAT), but also the content of ascorbic acid in both the stomach and liver to the levels comparable to ranitidine. In addition, the levels of malondialdehyde (MDA), a product of lipid peroxidation, were also significantly reduced in indomethacin-induced model of gastric ulcer (Bhatnagar et al., 2005). Orally given aqueous extract of Aegle marmelos fruits at a daily dose of $250 \mathrm{mg} / \mathrm{kg}$ body weight for 14 days significantly increased the content of reduced glutathione (GSH), and the activities of SOD and CAT in an animal model of aspirin-induced gastric ulcer (Das and Roy., 2012). Even only one hour prior to induction of gastric ulcer with aspirin, oral administration of extract of Punicagranatum $L$. fruits could dramatically increase the levels of SOD, CAT and glutathione peroxidase in the stomach in comparison with rats treated with aspirin alone (Ajaikumar et al., 2005). Extracts of both ginseng and Arctium lappa L. roots exhibit freeradical scavenging activity (Dos Santos et al., 2008; Jeong., 2002). Taken together, antiulcerogenic benefit of certain edible, natural ingredients could be attributed to their antioxidant property.

\section{b. Inhibition of acid secretion}

Increased acid secretion in part plays a role in the pathogenesis of gastric ulcer (Abdul-Aziz., 2011). Accordingly, sodium bicarbonate, a base, has been used to relieve the symptoms of gastric ulcer. Studies have shown that some edible natural ingredients prevent the development of gastric ulcer via inhibition of acid secretion in various animal models, including NSAID-induced gastric ulcer. Orally given Asparagus racemosus Willd. at a daily dose of $100 \mathrm{mg} / \mathrm{kg}$ body weight for 15 days markedly decreased the volume and acidity of gastric juice in a model of gastric ulcer induced by indomethacin (Bhatnagar et al., 2005). Likewise, oral administration of extract of Garcinia kola Heckel Seeds at a daily dose of $100 \mathrm{mg} / \mathrm{kg}$ body weight for 3 days induced an over $47 \%$ reduction in the volume of gastric juice and an over $45 \%$ increase in $\mathrm{pH}$ of the gastric juice (Olaleye and Farombi., 2006). There are several mechanisms involved in the inhibition of acid secretion induced by edible, natural ingredients. First, the enzyme $\mathrm{H}+\mathrm{K}+\mathrm{ATPase}$ in the gastric parietal cells is known to transports the $\mathrm{H}+$ against a concentration gradient, leading to acid secretion [110]. Extracts of certain ingredients such as ginseng, Arctium lappa L. roots and Garcinia kola Heckel seeds are potent inhibitors of H+, K+-ATPase (Dos Santos et al., 2008; Onasanwo et al., 2011; Oyagi et al., 2010). For example, the IC50 of Arctium lappa L. root extract for $\mathrm{H}+, \mathrm{K}+-\mathrm{ATPase}$ is $53 \square \mathrm{g} / \mathrm{ml}$ (Dos Santos et al., 2008). IC50 of Garcinia kola Heckel seed extract is $43.8 \square \mathrm{g} / \mathrm{ml}$ while IC50 of omeprazole, a conventional inhibitor, is $32.3 \square \mathrm{g} / \mathrm{ml}$ (Onasanwo et al., 2011). Second, histamine stimulates acid secretion while NSAIDs enhance the effect of histamine on acid secretion (Schwartzel et al., 1984; Shamburek and Schubert., 1992). Studies have demonstrated that oral administration of the extract of Trichosanthes cucumerina (aerial parts) was more effective then chlorpheniramine in reduction of wheal size induced by subcutaneous injection of histamine, suggesting antihistamine effect (Arawwawala et al., 2010). In addition, pre-feed rats with oral Potentilla fulgens Wall. ex Hook extract for 7 days significantly lowered histamine levels in the stomach tissue in a model of gastric ulcer (Laloo et al., 2013). Third, prostaglandin E2 inhibits acid secretion, and to protect stomach from the damage induced by indomethacin (Befrits and Johansson., 1985; Robert et al., 1981; Takeuchi., 2014). But NSAIDs lower prostaglandin E2 levels (el-Bayar et al., 1985). Inhibition of acid secretion by some ingredients could be through stimulating prostaglandin E2 production. Yokota et al. demonstrated that pre-feed rat with Eriobotrya japonica seed extract for 14 days increased prostaglandin E2 levels by 95\% in stomach tissue of indomethacin-induced ulcer (Yokota et al., 2011). Orally given $20 \mathrm{mg} / \mathrm{kg}$ body weight of Azadirachta indica seed extract is more potent than omeprazole $(10 \mathrm{mg} / \mathrm{kg}$ body weight) in elevation of prostaglandin E2 content in stomach tissue of aspirin-induced ulcer (Singh et al., 2015). Fourth, gastrin, a gastrointestinal hormone, can stimulate acid secretion independently or via histamine (Soll and Walsh., 1979). Treatment of rats with oral Solanum nigrum fruit extract dramatically lowered plasma levels of gastrin (Jainu and Devi., 2006). Additionally, serotonin can inhibit acid secretion (Bech., 1986). Treatment of rats with the extract of Aegle Marmelos fruits for 14 days could increase the serotonin content by $32 \%$ over aspirin treatment alone in an aspirin-induced gastric model (Singh et al., 2015). Collectively, edible, natural ingredients can inhibit $\mathrm{H}+, \mathrm{K}+-\mathrm{ATPase}$ activity, gastrin and histamine production while increase serotonin and prostaglandin E2 levels, leading to inhibition of acid secretion.

\section{c. Inhibition of inflammation}

Another feature of gastric ulcer is gastric inflammation, which is attributed in part to the NSAID-induced gastric ulcer (Sinha et al., 2013). Some ingredients that exert antiulcerogenic activity inhibit inflammation. In addition to an over $80 \%$ reduction in serum IL-1 $\square \square$ levels, pre-feed rats with grape seed extract at a daily dose of $100 \mathrm{mg} / \mathrm{kg}$ body weight for 6 days lowered serum TNF $\square$ to an undetectable level in indomethacin-induced gastric ulcer model (Kim et al., 2013). Likewise, co-administrations of ginger powder at a dose of $200 \mathrm{mg} / \mathrm{kg}$ body weight with aspirin for 4 hours induced an over $40 \%$ reduction in plasma TNF $\square$ and IL-1 $\square \square$ levels in comparison with aspirin alone (Wang et al., 2011). Moreover, edible ingredients also inhibit inflammatory cell infiltration. $30 \mathrm{~min}$ prior to induction of gastric ulcer with indomethacin, pre-feed 231 
Bi et al., Afr J Tradit Complement Altern Med., (2017) 14 (4): 221-238

https://doi.org/10.21010/ajtcam.v14i4.25

rats with extract of Bauhinia purpurea leaves provoked 100\% inhibition of leukocytes infiltration into gastric wall (Hisam et al., 2012). Similarly, both eosinophil and mast cell infiltration into mucosal wall were inhibited by oral administration of extract of a mixture containing Blumea balsamifera leaves, Curcuma domestica L. and Ammomum compactum S. pods 10 min prior to induction of gastric ulcer with aspirin (Mutmainah et al., 2014). Consistent with anti-inflammation, oral mourin also reduced the expression levels of Intercellular adhesion molecule-1 in gastric mucosa in a model of aspirininduced gastric ulcer (Sinha et al., 2015). Thus, inhibition of inflammation is another mechanism by which edible, natural ingredients prevent the development of NSAID-induced gastric ulcer.

\section{d. Others Mechanisms}

Heat shock protein 70(HSP70) is constitutively expresses in gastric mucosal cells. HSP70 plays a crucial role in protecting mucosal cells against NSAID-induced damage (Choi et al., 2009). Either overexpression or upregulation of HSP70 inhibits the gastric damage caused by indomethacin (Suemasu et al., 2009). Some edible ingredients protect stomach against NSAID-induced damage via upregulation of HSP70 expression. Studies have demonstrated that pretreatment of rats with ginger powder, or extract of Citrus lemon Burm. fruits or mourin significantly increased gastric HSP70 expression in NSAID-induced gastric ulcer [Rozza et al., 2011; Salah Khalil., 2015; Sinha et al., 2015).

One of the mechanisms that NSAIDs induce gastric damage is the reduction in mitochondrial dehydrogenase activity, leading to excessive oxidative stress (Maity et al., 2009). Morin can overcome the reduction in the mitochondrial dehydrogenase activity induced by indomethacin (Sinha et al., 2015). Other mechanisms of edible, natural ingredientsinduced gastric protection include the reduction in cell shedding and microvascular permeability (Laloo et al., 2013), upregulation of mucus content (Arawwawala et al., 2010; Bandyopadhyay et al., 2000; Batista et al., 2004) and mucosal glycoproteins (Mohan Kumar et al., 2006; Pimple et al., 2012), as well as mucosal cell proliferation (Laloo et al., 2013).

\section{Conclusions}

Edible, natural ingredients are effective for preventing the development of gastric ulcer induced by NSAIDs via divergent mechanisms. Because edible, natural ingredients are safe and widely available, they could be an optimal regimen for antiulcerogenesis, particularly for subjects who require long-term NSAID treatments. However, due to the lack of human clinical data and public awareness, these edible natural ingredients have not been widely deployed in clinical setting. Further clinical studies are required to validate the efficacy and safety of these ingredients for gastric ulcer.

Acknowledgement: This work was supported by Natural Science Foundation of China (81301360 and 81573075 for LH) and the Science Foundation of Tianjin Medical University (2013KY06 for Dr. LH).

Authors' Contributions: WB originated the concept, collected data and wrote draft; LH wrote draft; MQM critically reviewed the manuscript.

All Authors declare no conflicts of interest

\section{References}

1. Abbas, AM., Sakr, HF. (2013). Effect of selenium and grape seed extract on indomethacin-induced gastric ulcers in rats. J Physiol Biochem. 69:527-37.

2. Abdul-Aziz, K.K. (2011). Molecular Pathogenesis of Gastric Ulcer's Diseases and Strategies for Prevention. WebmedCentral GASTROENTEROLOGY 2: WMC001946 doi: 10.9754/journal.wmc.2011.001946

3. Adachi, M., Sakamoto, H., Kawamura, R., Wang, W., Imai, K., Shinomura, Y. (2007). Nonsteroidal anti-inflammatory drugs and oxidative stress in cancer cells. Histol Histopathol. 22:437-42.

4. Ajaikumar, K.B., Asheef, M., Babu, B.H., Padikkala, J. (2005). The inhibition of gastric mucosal injury by Punicagranatum L. (pomegranate) methanolic extract. J Ethnopharmacol. 96:171-6.

5. Akhtar, M.S., Munir, M. (1989). Evaluation of the gastric antiulcerogenic effects of Solanum nigrum, Brassica oleracea and Ocimum basilicum in rats. J Ethnopharmacol. 27:163-76.

6. al-Harbi, M.M., Islam, M.W., al-Shabanah, O.A., al-Gharably, N.M. (1995). Effect of acute administration of fish oil (omega-3 marine triglyceride) on gastric ulceration and secretion induced by various ulcerogenic and necrotizing agents in rats.Food Chem Toxicol. 33:553-8. 
Bi et al., Afr J Tradit Complement Altern Med., (2017) 14 (4): 221-238

https://doi.org/10.21010/ajtcam.v14i4.25

7. Al-Howiriny, T., Alsheikh, A., Alqasoumi, S., Al-Yahya, M., ElTahir, K., Rafatullah, S. (2010). Gastric antiulcer, antisecretory and cytoprotective properties of celery (Apium graveolens) in rats. Pharm Biol. 48:786-93.

8. Al-Howiriny, T., Al-Sohaibani, M., El-Tahir, K., Rafatullah, S. (2003). Prevention of experimentally-induced gastric ulcers in rats by an ethanolic extract of "Parsley" Petroselinum crispum.Am J Chin Med. 31:699-711.

9. Alimi, H., Hfaiedh, N., Bouoni, Z., Hfaiedh, M., Sakly, M., Zourgui, L., Rhouma, K.B. (2010). Antioxidant and antiulcerogenic activities of Opuntia ficus indica f. inermis root extract in rats. Phytomedicine. 17:1120-6.

10. Alimi, H., Hfaiedh, N., Bouoni, Z., Sakly, M., Ben Rhouma, K. (2011). Evaluation of antioxidant and antiulcerogenic activities of Opuntia ficus indica f. inermis flowers extract in rats. Environ Toxicol Pharmacol. 32:406-16

11. Alimi, H., Mbarki, S., Barka, Z.B., Feriani, A., Bouoni, Z., Hfaeidh, N., Sakly, M., Tebourbi, O., Rhouma, K.B. (2013). Phytochemical, antioxidant and protective effect of Rhus tripartitum root bark extract against ethanol-induced ulcer in rats. Gen Physiol Biophys. 32:115-27.

12. al-Shabanah, O.A. (1997). Effect of evening primrose oil on gastric ulceration and secretion induced by various ulcerogenic and necrotizing agents in rats. Food Chem Toxicol.35:769-75.

13. Andreo, M.A., Ballesteros, K.V., Hiruma-Lima, C.A., Machado da Rocha, L.R., Souza Brito, A.R., Vilegas, W. (2006). Effect of Mouriri pusa extracts on experimentally induced gastric lesions in rodents: role of endogenous sulfhydryls compounds and nitric oxide in gastroprotection. J Ethnopharmacol. 107:431-41.

14. Antonisamy, P., Arasu, M.V., Dhanasekaran, M., Choi, K.C., Aravinthan, A., Kim, N.S., Kang, C.W., Kim, J.H. (2016) Protective effects of trigonelline against indomethacin-induced gastric ulcer in rats and potential underlying mechanisms. Food Funct. 7:398-408.

15. Arawwawala, L.D., Thabrew, M.I., Arambewela, L.S. (2010). Gastroprotective activity of Trichosanthes cucumerina in rats. J Ethnopharmacol. 127:750-4.

16. Aro, P., Storskrubb, T., Ronkainen, J., Bolling-Sternevald, E., Engstrand, L., Vieth, M., Stolte, M., Talley, N.J., Agréus, L. (2006). Peptic ulcer disease in a general adult population: the Kalixanda study: a random population-based study. Am J Epidemiol. 006;163:1025-34

17. Bago, J., Galović, A., Belosić Halle, Z., Bilić, A., Bevanda, M., Bago, P. (2004). Comparison of the efficacy of $250 \mathrm{mg}$ and $500 \mathrm{mg}$ clarithromycin used with lansoprazole and amoxicillin in eradication regimens for Helicobacter pylori infection. Wien Klin Wochenschr. 116:495-9.

18. Bandyopadhyay, S.K., Pakrashi, S.C., Pakrashi, A. (2000). The role of antioxidant activity of Phyllanthus emblica fruits on prevention from indomethacin induced gastric ulcer. J Ethnopharmacol. 70:171-6.

19. Barkun, A., Leontiadis, G. (2010). Systematic review of the symptom burden, quality of life impairment and costs associated with peptic ulcer disease. Am J Med. 123:358-66. e2.

20. Barros, M.P., Lemos, M., Maistro, E.L., Leite, M.F., Sousa, J.P., Bastos, J.K., Andrade, S.F. (2008). Evaluation of antiulcer activity of the main phenolic acids found in Brazilian Green Propolis. J Ethnopharmacol. 120:372-7.

21. Batista, L.M., de Almeida, A.B., de Pietro Magri, L., Toma, W., Calvo, T.R., Vilegas, W., Souza Brito, A.R. (2004) Gastric antiulcer activity of Syngonanthus arthrotrichus SILVEIRA. Biol Pharm Bull. 27:328-32.

22. Bech, K. (1986) Effect of serotonin on bethanechol-stimulated gastric acid secretion and gastric antral motility in dogs. Scand J Gastroenterol. 21:655-61.

23. Befrits, R., Johansson, C. (1985) Oral PGE2 inhibits gastric acid secretion in man. Prostaglandins. 29:143-52.

24. Bhatnagar, M., Sisodia, S.S. (2006) Antisecretory and antiulcer activity of Asparagus racemosus Willd. against indomethacin plus phyloric ligation-induced gastric ulcer in rats. J Herb Pharmacother. 6:13-20.

25. Bhatnagar, M., Sisodia, S.S., Bhatnagar, R. (2005). Antiulcer and antioxidant activity of Asparagus racemosus Willd and Withania somnifera Dunal in rats. Ann N Y Acad Sci. 1056:261-78.

26. Bhattacharyya, A., Chattopadhyay, R., Mitra, S., Crowe, S.E. (2014) Oxidative stress: an essential factor in the pathogenesis of gastrointestinal mucosal diseases. Physiol Rev. 94:329-54.

27. Bonamin, F., Moraes, T.M., Dos, Santos, R.C., Kushima, H., Faria, F.M., Silva, M.A., Junior, I.V., Nogueira, L., Bauab, T.M., Souza, Brito. A.R., da Rocha, L.R., Hiruma-Lima, C.A. (2014). The effect of a minor constituent of essential oil from Citrus aurantium: the role of $\beta$-myrcene in preventing peptic ulcer disease.Chem Biol Interact. 212:11-9.

28. Bujanda, L. (2000) The effects of alcohol consumption upon the gastrointestinal tract. Am J Gastroenterol. 95:3374-82.

29. Carli, D.M., Pires, R.C., Rohde, S.L., Kavalco, C.M., Fagundes, R.B. (2015) Peptic ulcer frequency differences related to h. Pylori or aines. Arq Gastroenterol. 52:46-9.

30. Choi, S.R., Lee, S.A., Kim, Y.J., Ok, C.Y., Lee, H.J., Hahm, K.B. (2009) Role of heat shock proteins in gastric inflammation and ulcer healing. J Physiol Pharmacol. 60:5-17.

31. Choi, Y.H., Kim, Y.J., Chae, H.S., Chin, Y.W. (2015) In vivo gastroprotective effect along with pharmacokinetics, tissue distribution and metabolism of isoliquiritigenin in mice. Planta Med. 81:586-93.

32. Cilliers, A., Adler, A.J., Saloojee, H. (2015) Anti-inflammatory treatment for carditis in acute rheumatic fever. Cochrane Database Syst Rev. 5:CD003176. 
Bi et al., Afr J Tradit Complement Altern Med., (2017) 14 (4): 221-238

https://doi.org/10.21010/ajtcam.v14i4.25

33. Coelho-de-Souza, A.N., Lahlou, S., Barreto, J.E., Yum, M.E., Oliveira, A.C, Oliveira, H.D., Celedônio, N.R., Feitosa, R.G., Duarte, G.P., Santos, C.F., de Albuquerque, A.A., Leal-Cardoso, J.H. (2013) Essential oil of Croton zehntneri and its major constituent anethole display gastroprotective effect by increasing the surface mucous layer. Fundam Clin Pharmacol. 27:288-98.

34. Cremonesi, G., Cavalieri, L. (2015) Efficacy and safety of morniflumate for the treatment of symptoms associated with soft tissue inflammation. J Int Med Res. 43:290-302.

35. Das, S.K., Roy, C. (2012) The protective role of Aegle marmelos on aspirin-induced gastro-duodenal ulceration in albino rat model: a possible involvement of antioxidants. Saudi J Gastroenterol. 18:188-94.

36. de Almeida, A.B., Luiz-Ferreira, A., Cola, M., Di Pietro Magri, L., Batista, L.M., de Paiva, J.A., Trigo, J.R., SouzaBrito, A.R. (2012) Anti-ulcerogenic mechanisms of the sesquiterpene lactone onopordopicrin-enriched fraction from Arctium lappa L. (Asteraceae): role of somatostatin, gastrin, and endogenous sulfhydryls and nitric oxide. J Med Food. 15:378-83.

37. de Barros, M.P., Sousa, J.P., Bastos, J.K., de Andrade, S.F. (2007) Effect of Brazilian green propolis on experimental gastric ulcers in rats. J Ethnopharmacol. 110:567-71

38. de Morais Lima, G.R., de Albuquerque Montenegro, C., de Sousa Falcão, H., de Jesus, N.Z., Cabral, A.G., Gomes, I.F., Agra Mde, F., Tavares, J.F., Batista, L.M. (2013) Gastroprotective activity of the ethanolic extract and hexane phase of Combretum duarteanum Cambess. (Combretaceae). J Nat Med. 67:492-502.

39. Dehmer, S.P., Maciosek, M.V., Flottemesch, T.J., LaFrance, A.B., Whitlock, E.P. (2016) Aspirin for the Primary Prevention of Cardiovascular Disease and Colorectal Cancer: A Decision Analysis for the U.S. Preventive Services Task Force. Ann Intern Med. doi: 10.7326/M15-2129.

40. Devaraj, V.C., Krishna, B.G. (2011) Gastric antisecretory and cytoprotective effects of leaf extracts of Amaranthus tricolor Linn. in rats. Zhong Xi Yi Jie He Xue Bao. 9:1031-8.

41. Dos Santos, A.C., Baggio, C.H., Freitas, C.S., Lepieszynski, J., Mayer, B., Twardowschy, A., Missau, F.C., dos Santos, E.P., Pizzolatti, M.G., Marques, M.C. (2008) Gastroprotective activity of the chloroform extract of the roots from Arctium lappa L. J Pharm Pharmacol. 60:795-801.

42. Duggan, J.M., O'Keefe, E.A., Weaver, A.L., Zinsmeister, A.R., Melton, L.J. 3rd. (1992) Diabetes mellitus and operated peptic ulcer disease. J Gastroenterol Hepatol. 7:308-12.

43. el-Bayar, H., Steel, L., Montcalm, E., Danquechin-Dorval, E., Dubois, A., Shea-Donohue, T. (1985) The role of endogenous prostaglandins in the regulation of gastric secretion in rhesus monkeys. Prostaglandins. 30:401-17.

44. Enthoven, W.T., Roelofs, P.D., Deyo, R.A., van Tulder, M.W., Koes, B.W. (2016) Non-steroidal anti-inflammatory drugs for chronic low back pain.Cochrane Database Syst Rev.;2:CD012087.

45. García Rodríguez, L.A., Hernández-Díaz, S. (2001) Relative risk of upper gastrointestinal complications among users of acetaminophen and nonsteroidal anti-inflammatory drugs. Epidemiology. 12:570-6.

46. García Rodríguez, L.A., Hernández-Díaz, S. (2004) Risk of uncomplicated peptic ulcer among users of aspirin and nonaspirin nonsteroidal antiinflammatory drugs. Am J Epidemiol. 159:23-31.

47. Ghosh, R., Alajbegovic, A., Gomes, A.V. (2015) NSAIDs and Cardiovascular Diseases: Role of Reactive Oxygen Species. Oxid Med Cell Longev. 2015:536962.

48. Gloria, V.I., Domingo, E.O., Makalinao, A.U., Zano, F.M., Rasco, E.T., Sy, C.T. (1989) Omeprazole $20 \mathrm{mg}$ and $40 \mathrm{mg}$ daily in the treatment of gastric ulcer: a pilot study in Filipino patients. J Gastroenterol Hepatol. 4:63-8.

49. Goel, R.K., Chakrabarti, A., Sanyal, A.K. (1985) The effect of biological variables on the anti-ulcerogenic effect of vegetable plantain banana. Planta Med. 2:85-8.

50. Goel, R.K., Gupta, S., Shankar, R., Sanyal, A.K. (1986) Anti-ulcerogenic effect of banana powder (Musa sapientum var. paradisiaca) and its effect on mucosal resistance. J Ethnopharmacol. 18:33-44.

51. Goel, R.K., Sairam, K., Rao, C.V. (2001). Role of gastric antioxidant and anti-Helicobactor pylori activities in antiulcerogenic activity of plantain banana (Musa sapientum var. paradisiaca). Indian J Exp Biol. 39:719-22.

52. Graham, D.Y., Agrawal, N.M., Campbell, D.R., Haber, M.M., Collis, C., Lukasik, N.L, Huang, B. (2002) Ulcer prevention in long-term users of nonsteroidal anti-inflammatory drugs: results of a double-blind, randomized, multicenter, active- and placebo-controlled study of misoprostol vs lansoprazole. Arch Intern Med. 162:169-75.

53. Hansson, L.E., Nyrén, O., Hsing, A.W., Bergström, R., Josefsson, S., Chow, W.H., Fraumeni, J.F. Jr., Adami, H.O. (1996) The risk of stomach cancer in patients with gastric or duodenal ulcer disease. N Engl J Med. 335:242-9.

54. Hawkey, C.J., Karrasch, J.A., Szczepañski, L., Walker, D.G., Barkun, A., Swannell, A.J., Yeomans, N.D. (1998) Omeprazole compared with misoprostol for ulcers associated with nonsteroidal antiinflammatory drugs. Omeprazole versus Misoprostol for NSAID-induced Ulcer Management (OMNIUM) Study Group. N Engl J Med. 338:727-34.

55. Hiraishi, H., Shimada, T., Terano, A. (2000) Involvement of oxidative stress in the pathogenesis of NSAID-induced gastric mucosal damage. J Gastroenterol. 35:567-9.

56. Hisam, E.E., Zakaria, Z.A., Mohtaruddin, N., Rofiee, M.S., Hamid, H.A., Othman, F. (2012) Antiulcer activity of the chloroform extract of Bauhinia purpurea leaf. Pharm Biol. 50:1498-507. 
Bi et al., Afr J Tradit Complement Altern Med., (2017) 14 (4): 221-238

https://doi.org/10.21010/ajtcam.v14i4.25

57. Hsiao, F.Y., Tsai, Y.W., Huang, W.F., Wen, Y.W., Chen, P.F., Chang, P.Y., Kuo, K.N. (2009) A comparison of aspirin and clopidogrel with or without proton pump inhibitors for the secondary prevention of cardiovascular events in patients at high risk for gastrointestinal bleeding. Clin Ther. 31:2038-47.

58. Ikeda, S., Tamamuro, T., Hamashima, C., Asaka, M. (2001) Evaluation of the cost-effectiveness of Helicobacter pylori eradication triple therapy vs. conventional therapy for ulcers in Japan. Aliment Pharmacol Ther. 15:1777-85.

59. Jainu, M., Devi, C.S. (2006) Antiulcerogenic and ulcer healing effects of Solanum nigrum (L.) on experimental ulcer models: possible mechanism for the inhibition of acid formation. J Ethnopharmacol. 104:156-63.

60. Jamal, A., Javed, K., Aslam, M., Jafri, M.A. (2006) Gastroprotective effect of cardamom, Elettaria cardamomum Maton. fruits in rats. J Ethnopharmacol. 103:149-53.

61. Jeong, C.S. (2002) Effect of butanol fraction of Panax ginseng head on gastric lesion and ulcer. Arch Pharm Res. 25:61-6.

62. Kang, J.M., Kim, N., Lee, B.H., Park, H.K., Jo, H.J., Shin, C.M., Lee, S.H., Park, Y.S., Hwang, J.H., Kim, J.W., Jeong, S.H., Lee, D.H., Jung, H.C., Song, I.S.(2011) Risk factors for peptic ulcer bleeding in terms of Helicobacter pylori, NSAIDs, and antiplatelet agents. Scand J Gastroenterol. 46:1295-301.

63. Kang, J.M., Seo, P.J., Kim, N., Lee, B.H., Kwon, J., Lee, D.H., Jung, H.C. (2012) Analysis of direct medical care costs of peptic ulcer disease in a Korean tertiary medical center. Scand J Gastroenterol. 47:36-42.

64. Kim, T.H., Jeon, E.J., Cheung, D.Y., Kim, C.W., Kim, S.S., Park, S.H., Han, S.W., Kim, M.J., Lee, Y.S., Cho, M.L., Chang, J.H., Min, J.K., Kim, J.I. (2013) Gastroprotective Effects of Grape Seed Proanthocyanidin Extracts against Nonsteroid Anti-Inflammatory Drug-Induced Gastric Injury in Rats. Gut Liver. 7:282-9.

65. Ko, J.K., Cho, C.H. (2000) Alcohol drinking and cigarette smoking: a "partner" for gastric ulceration. Zhonghua Yi Xue Za Zhi (Taipei). 63:845-54.

66. Köhler, O., Benros, M.E., Nordentoft, M., Farkouh, M.E., Iyengar, R.L., Mors, O., Krogh, J. (2014) Effect of antiinflammatory treatment on depression, depressive symptoms, and adverse effects: a systematic review and metaanalysis of randomized clinical trials. JAMA Psychiatry. 71:1381-91

67. Konturek, S.J., Bielański, W., Płonka, M., Pawlik, T., Pepera, J., Konturek, P.C., Czarnecki, J., Penar, A., Jedrychowski, W. (2003) Helicobacter pylori, non-steroidal anti-inflammatory drugs and smoking in risk pattern of gastroduodenal ulcers. Scand J Gastroenterol. 38:923-30.

68. Kumar, D., Hegde, H.V., Patil, P.A., Roy, S., Kholkute, S.D. (2013) Antiulcer activity of water soaked Glycine max L. grains in aspirin induced model of gastric ulcer in Wistar rats. J Ayurveda Integr Med. 4:134-7.

69. Laloo, D., Prasad, S.K., Krishnamurthy, S., Hemalatha, S. (2013) Gastroprotective activity of ethanolic root extract of Potentilla fulgens Wall. ex Hook. J Ethnopharmacol. 146:505-14.

70. Lee, E.B., Hyun, J.E., Li, D.W., Moon, Y.I. (2002) Effects of Opuntia ficus-indica var. Saboten stem on gastric damages in rats. Arch Pharm Res. 25:67-70.

71. Lee, O.Y., Kang, D.H., Lee, D.H., Chung, I.K., Jang, J.Y., Kim, J.I., Cho, J.W., Rew, J.S., Lee, K.M., Kim, K.O., Choi, M.G., Lee, S.W., Lee, S.T., Kim, T.O., Shin, Y.W., Seol, S.Y. (2014) A comparative study of DA-9601 and misoprostol for prevention of NSAID-associated gastroduodenal injury in patients undergoing chronic NSAID treatment. Arch Pharm Res. 37:1308-16.

72. Lemos, M., de Barros, M.P., Sousa, J.P., da Silva Filho, A.A., Bastos, J.K., de Andrade, S.F. (2007) Baccharis dracunculifolia, the main botanical source of Brazilian green propolis, displays antiulcer activity. J Pharm Pharmacol. 59:603-8.

73. Lemos, M., Santin, J.R., Júnior, L.C., Niero, R., Andrade, S.F. (2011) Gastroprotective activity of hydroalcoholic extract obtained from the leaves of Brassica oleracea var. acephala DC in different animal models. J Ethnopharmacol. 138:503-7.

74. Lewis, D.A., Fields, W.N., Shaw, G.P. (1999) A natural flavonoid present in unripe plantain banana pulp (Musa sapientum L. var. paradisiaca) protects the gastric mucosa from aspirin-induced erosions.J Ethnopharmacol. 65:283-8.

75. Li, Z., Zou, D., Ma, X., Chen, J., Shi, X., Gong, Y, Man, X., Gao, L., Zhao, Y., Wang, R., Yan, X., Dent, J., Sung, J.J., Wernersson, B., Johansson, S., Liu, W., He, J. (2010) Epidemiology of peptic ulcer disease: endoscopic results of the systematic investigation of gastrointestinal disease in China. Am J Gastroenterol. 105:2570-7.

76. Lim, J.H., Kim, J.H., Kim, N., Lee, B.H., Seo, P.J., Kang, J.M., Jo, S.Y., Park, J.H., Nam, R.H., Chang, H., Kwon, J.W., Lee, D.H. Gastroprotective effect of Cochinchina momordica seed extract in nonsteroidal anti-inflammatory drug-induced acute gastric damage in a rat model.Gut Liver. 2014 Jan;8(1):49-57.

77. Maity, P., Bindu, S., Dey, S., Goyal, M., Alam, A., Pal, C., Mitra, K., Bandyopadhyay, U. (2009) Indomethacin, a nonsteroidal anti-inflammatory drug, develops gastropathy by inducing reactive oxygen species-mediated mitochondrial pathology and associated apoptosis in gastric mucosa: a novel role of mitochondrial aconitase oxidation. J Biol Chem. 284:3058-68 


\title{
Bi et al., Afr J Tradit Complement Altern Med., (2017) 14 (4): 221-238
}

\author{
https://doi.org/10.21010/ajtcam.v14i4.25
}

78. Majeed, W., Aslam, B., Javed, I., Khaliq, T., Muhammad, F., Ali, A., Raza, A. (2015) Histopathological evaluation of gastro protective effect of Berberis vulgaris (Zereshk) seeds against aspirin induced ulcer in albino mice. Pak J Pharm Sci. 28:1953-8.

79. Masclee, G.M., Coloma, P.M., Kuipers, E.J., Sturkenboom, M.C. (2015). Increased risk of microscopic colitis with use of proton pump inhibitors and non-steroidal anti-inflammatory drugs. Am J Gastroenterol. 110:749-59.

80. Massignani, J.J., Lemos, M., Maistro, E.L., Schaphauser, H.P., Jorge, R.F., Sousa, J.P., Bastos, J.K., de Andrade, S.F. (2009) Antiulcerogenic activity of the essential oil of Baccharis dracunculifolia on different experimental models in rats. Phytother Res. 23:1355-60

81. Masuda, H., Inoue, S., Arakawa, H., Koizumi, K., Kubo, N. (1976) Peptic ulcer in diabetes mellitus. Gastroenterol Jpn. $11: 1-4$.

82. McAnulty, S., McAnulty, L., Nieman, D., Morrow, J., Dumke, C., Henson, D. (2007) Effect of NSAID on muscle injury and oxidative stress. Int J Sports Med. 28:909-15.

83. Mohan Kumar, M., Joshi, M.C., Prabha, T., Dorababu, M., Goel, R.K. (2006) Effect of plantain banana on gastric ulceration in NIDDM rats: role of gastric mucosal glycoproteins, cell proliferation, antioxidants and free radicals. Indian J Exp Biol. 44:292-9.

84. Molloy, R.M., Sonnenberg, A. (1997) Relation between gastric cancer and previous peptic ulcer disease. Gut. 40:24752

85. Mutmainah., Susilowati, R., Rahmawati, N., Nugroho, A.E. (2014) Gastroprotective effects of combination of hot water extracts of turmeric (Curcuma domestica L.), cardamom pods (Ammomum compactum S.) and sembung leaf (Blumea balsamifera DC.) against aspirin-induced gastric ulcer model in rats. Asian Pac J Trop Biomed. 4:S500-4.

86. Nartey, E.T., Ofosuhene, M., Kudzi, W., Agbale, C.M. (2012) Antioxidant and gastric cytoprotective prostaglandins properties of Cassia sieberiana roots bark extract as an anti-ulcerogenic agent. BMC Complement Altern Med. 12:65.

87. Olaleye, S.B., Farombi, E.O. (2006) Attenuation of indomethacin- and $\mathrm{HCl} /$ ethanol-induced oxidative gastric mucosa damage in rats by kolaviron, a natural biflavonoid of Garcinia kola seed. Phytother Res. 20:14-20.

88. Oloyede, H.O., Adaja, M.C., Ajiboye, T.O., Salawu, M.O. (2015) Anti-ulcerogenic activity of aqueous extract of Carica papaya seed on indomethacin-induced peptic ulcer in male albino rats. J Integr Med. 13:105-14.

89. Onasanwo, S.A., Singh, N., Olaleye, S.B., Palit, G. (2011) Anti-ulcerogenic and proton pump (H+, K+ ATPase) inhibitory activity of Kolaviron from Garcinia kola Heckel in rodents. Indian J Exp Biol. 49:461-8.

90. Oyagi, A., Ogawa, K., Kakino, M., Hara, H. (2010) Protective effects of a gastrointestinal agent containing Korean red ginseng on gastric ulcer models in mice. BMC Complement Altern Med. 10:45.

91. Ozdil, K., Kahraman, R., Sahin, A., Calhan, T., Gozden, E.H., Akyuz, U., Erer, B., Sokmen, M.H. (2013) Bone density in proton pump inhibitors users: a prospective study. Rheumatol Int. 33:2255-60.

92. Pimple, B.P., Kadam, P.V., Patil, M.J. (2012) Protective effect of Luffa acutangula extracts on gastric ulceration in NIDDM rats: role of gastric mucosal glycoproteins and antioxidants. Asian Pac J Trop Med. 5:610-5.

93. Pipaliya, N., Solanke, D., Rathi, C., Patel, R., Ingle, M., Sawant, P. (2016) Esomeprazole induced galactorrhea: a novel side effect. Clin J Gastroenterol. 9:13-6.

94. Prichard, P., Brown, G., Bhaskar, N., Hawkey, C. (1988) The effect of dietary fatty acids on the gastric production of prostaglandins and aspirin-induced injury. Aliment Pharmacol Ther. 2:179-84.

95. Repetto, M.G., Llesuy, S.F. (2002) Antioxidant properties of natural compounds used in popular medicine for gastric ulcers. Braz J Med Biol Res. 35:523-34.

96. Robert, A., Kane, G., Reele, S.B. (1981) Dose response inhibition in man of meal-stimulated gastric acid secretion by 15(R)-15-methyl prostaglandin E2, given orally. Gut. 22:728-31.

97. Rozza, A.L., Moraes Tde, M., Kushima, H., Tanimoto, A., Marques, M.O., Bauab, T.M., Hiruma-Lima, C.A., Pellizzon, C.H. (2011) Gastroprotective mechanisms of Citrus lemon (Rutaceae) essential oil and its majority compounds limonene and $\beta$-pinene: involvement of heat-shock protein-70, vasoactive intestinal peptide, glutathione, sulfhydryl compounds, nitric oxide and prostaglandin $\mathrm{E}_{2}$. Chem Biol Interact. 189:82-9.

98. Rujjanawate, C., Kanjanapothi, D., Amornlerdpison, D., Pojanagaroon, S. (2005) Anti-gastric ulcer effect of Kaempferia parviflora. J Ethnopharmacol. 102:120-2.

99. Sachs, G., Wallmark, B. (1989). The gastric H+,K+-ATPase: the site of action of omeprazole. Scand J Gastroenterol Suppl. 166:3-11.

100.Sairam, K., Priyambada, S., Aryya, N.C., Goel, R.K. (2003) Gastroduodenal ulcer protective activity of Asparagus racemosus: an experimental, biochemical and histological study. J Ethnopharmacol. 86:1-10.

101.Salah Khalil, M. (2015) The postulated mechanism of the protective effect of ginger on the aspirin induced gastric ulcer: Histological and immunohistochemical studies. Histol Histopathol. 30:855-64.

102.Scheiman, J.M.(2013a). The use of proton pump inhibitors in treating and preventing NSAID-induced mucosal damage. Arthritis Res Ther. 15 Suppl 3:S5. 
Bi et al., Afr J Tradit Complement Altern Med., (2017) 14 (4): 221-238

https://doi.org/10.21010/ajtcam.v14i4.25

103.Scheiman, J.M., Herlitz. J., Veldhuyzen van Zanten,S.J., Lanas, A., Agewall, S., Nauclér, E.C., Svedberg, L.E., Nagy, P.(2013b). Esomeprazole for prevention and resolution of upper gastrointestinal symptoms in patients treated with low-dose acetylsalicylic acid for cardiovascular protection: the OBERON trial. J Cardiovasc Pharmacol.61:250-7.

104.Scheiman, J.M., Yeomans, N.D., Talley, N.J., Vakil, N., Chan, F.K., Tulassay, Z., Rainoldi, J.L., Szczepanski, L., Ung, K.A, Kleczkowski, D., Ahlbom, H., Naesdal, J., Hawkey, C. (2006) Prevention of ulcers by esomeprazole in at-risk patients using non-selective NSAIDs and COX-2 inhibitors. Am J Gastroenterol. 101:701-10.

105.Schwartzel, E.H. Jr., Levine, R.A., Schwartz, S.E., Ganley, C.E. (1984) Indomethacin enhances histamine-stimulated acid production in rabbit isolated fundic glands. Prostaglandins Leukot Med. 14:383-90.

106.Shamburek, R.D., Schubert, M.L. (1992) Control of gastric acid secretion. Histamine H2-receptor antagonists and $\mathrm{H}+\mathrm{K}(+)$-ATPase inhibitors. Gastroenterol Clin North Am. 21:527-50

107.Singh, P., Dutta, S.R., Guha, D. (2015) Gastric mucosal protection by aegle marmelos against gastric mucosal damage: role of enterochromaffin cell and serotonin. Saudi J Gastroenterol. 21:35-42.

108.Singh, R., Mishra, V., Pandeti, S., Palit, G., Barthwal, M.K., Pandey, H.P, Narender, T. (2015) Cytoprotective and Anti-secretory. Effects of Azadiradione Isolated from the Seeds of Azadirachta indica (neem) on Gastric Ulcers in Rat Models. Phytother Res. 29:910-6.

109.Singh, R., Mishra, V., Pandeti, S., Palit, G., Barthwal, M.K., Pandey, H.P., Narender, T. (2015) Cytoprotective and Anti-secretory. Effects of Azadiradione Isolated from the Seeds of Azadirachta indica (neem) on Gastric Ulcers in Rat Models.Phytother Res. 29:910-6.

110.Singh, S. (1999) Evaluation of gastric anti-ulcer activity of fixed oil of Ocimum basilicum Linn. and its possible mechanism of action. Indian J Exp Biol. 37:253-7.

111.Sinha, K., Sadhukhan, P., Saha, S., Pal, P.B., Sil, P.C. (2015) Morin protects gastric mucosa from nonsteroidal antiinflammatory drug, indomethacin induced inflammatory damage and apoptosis by modulating NF- $\mathrm{B}$ pathway. Biochim Biophys Acta. 1850:769-83.

112.Sinha, M., Gautam, L., Shukla, P.K., Kaur, P., Sharma, S., Singh, T.P. (2013) Current perspectives in NSAID-induced gastropathy. Mediators Inflamm. 2013:258209.

113.Soll, A.H., Walsh, J.H. (1979) Regulation of gastric acid secretion. Annu Rev Physiol. 41:35-53.

114.Sonnenberg, A., Everhart, J.E. (1997) Health impact of peptic ulcer in the United States. Am J Gastroenterol. 92:61420.

115.Suemasu, S., Tanaka, K., Namba, T., Ishihara, T., Katsu, T., Fujimoto, M., Adachi, H., Sobue, G., Takeuchi, K., Nakai, A., Mizushima, T. (2009) A role for HSP70 in protecting against indomethacin-induced gastric lesions. J Biol Chem. 284:19705-15.

116.Sylvester, K.W., Cheng, J.W., Mehra, M.R. (2013) Esomeprazole and aspirin fixed combination for the prevention of cardiovascular events. Vasc Health Risk Manag. 9:245-54.

117. Takeuchi, K. (2014) Gastric cytoprotection by prostaglandin $E_{2}$ and prostacyclin: relationship to EP1 and IP receptors. J Physiol Pharmacol. 65:3-14.

118.Tandon, R., Khanna, H.D., Dorababu, M., Goel, R.K. (2004) Oxidative stress and antioxidants status in peptic ulcer and gastric carcinoma. Indian J Physiol Pharmacol. 48:115-8.

119.Taniyama, K., Shimbo, T., Iwase, H., Tanaka, S., Watanabe, N., Uemura, N. (2011) Evidence-based therapy according to the guideline for gastric ulcers is cost-effective in Japan. J Physiol Pharmacol. 62:627-35.

120.Verhaegh, B.P., de Vries, F., Masclee, A.A., Keshavarzian, A., de Boer, A., Souverein, P.C., Pierik, M.J., Jonkers, D.M. (2016) High risk of drug-induced microscopic colitis with concomitant use of NSAIDs and proton pump inhibitors. Aliment Pharmacol Ther. 43:1004-13.

121.Voutilainen, M., Mäntynen, T., Färkkilä, M., Juhola, M., Sipponen, P. (2001) Impact of non-steroidal antiinflammatory drug and aspirin use on the prevalence of dyspepsia and uncomplicated peptic ulcer disease. Scand J Gastroenterol. 36:817-21.

122.Wang, F.W., Tu, M.S., Mar, G.Y., Chuang, H.Y., Yu, H.C., Cheng, L.C., Hsu, P.I. (2011) Prevalence and risk factors of asymptomatic peptic ulcer disease in Taiwan. World J Gastroenterol. 17:1199-203.

123.Wang, Z., Hasegawa, J., Wang, X., Matsuda, A., Tokuda, T., Miura, N., Watanabe, T. (2011). Protective Effects of Ginger against Aspirin-Induced Gastric Ulcers in Rats. Yonago Acta Med. 54:11-9.

124.Wang, Z.T., Du, Q., Xu, G.J., Wang, R.J., Fu, D.Z., Ng, T.B. (1997) Investigations on the protective action of Condonopsis pilosula (Dangshen) extract on experimentally-induced gastric ulcer in rats. Gen Pharmacol. 28:469-73.

125. Yamagata, M., Hiraishi, H. (2007) [Prevalence and incidence of NSAID-induced gastrointestinal ulcers and bleeding]. Nihon Rinsho. 65:1749-53.

126. Yokota, J., Kitaoka, T., Jobu, K., Takuma, D., Hamada, A., Onogawa, M., Yoshioka, S., Kyotani, S., Miyamura, M. (2011). Eriobotrya japonica seed extract and deep sea water protect against indomethacin-induced gastric mucosal injury in rats. J Nat Med. 65:9-17. 
Bi et al., Afr J Tradit Complement Altern Med., (2017) 14 (4): 221-238

https://doi.org/10.21010/ajtcam.v14i4.25

127.Yokota, J., Takuma, D., Hamada, A., Onogawa, M., Yoshioka, S., Kusunose, M., Miyamura, M., Kyotani, S., Nishioka, Y. (2008) Gastroprotective activity of Eriobotrya japonica seed extract on experimentally induced gastric lesions in rats. J Nat Med. 62:96-100.

128.Zakaria, Z.A., Abdul Hisam, E.E., Norhafizah, M., Rofiee, M.S., Othman, F., Hasiah, A.H., Vasudevan, M. (2012) Methanol extract of Bauhinia purpurea leaf possesses anti-ulcer activity. Med Princ Pract. 21:476-82.

129.Zakaria, Z.A., Abdul Hisam, E.E., Rofiee, M.S., Norhafizah, M., Somchit, M.N., Teh, L.K., Salleh, M.Z. (2011) In vivo antiulcer activity of the aqueous extract of Bauhinia purpurea leaf. J Ethnopharmacol. 137:1047-54. 